\title{
THE OCCURRENCE OF ROYAL FLAGFIN Aulopus filamentosus (Bloch, 1792) IN MERSIN BAY (NORTH-EASTERN MEDITERRANEAN) TURKEY
}

\author{
Deniz Erguden ${ }^{1 *}$, Yusuf Kenan Bayhan ${ }^{2}$, Sibel Alagoz Erguden ${ }^{3}$, Ayhan Altun ${ }^{1}$ \\ 'Department of Marine Science, Marine Sciences and Technology Faculty, Iskenderun Technical University, TR \\ 31220, Iskenderun, Hatay, Turkey \\ Fisheries Department, Kahta Vocational School, Adiyaman University, TR 02400, Kahta, Adiyaman, Turkey \\ ${ }^{3}$ Fisheries Department, Imamoglu Vocational School, Cukurova University, TR 01700, Imamoglu, Adana, Turkey \\ *Corresponding Author, Email: deniz.erguden@iste.edu.tr
}

\section{ARTICLE INFO}

Received: 5 February 2017

Received in revised form: 20 October 2017

Accepted: 10 November 2017

Available online: 22 November 2017

\section{Keywords:}

Aulopus filamentosus

Mersin Bay

Mediterranean Sea

Turkey

How to Cite

\begin{abstract}
Three specimens (1 male and 2 females) of royal flagfin Aulopus filamentosus (Bloch, 1792) were caught at a depth of $184 \mathrm{~m}$ off Erdemli, Mersin Bay (northeastern Mediterranean, Turkey) in June 2015. The present paper reports the first occurrence and is the confirmation of royal flagfin A. filamentosus from the northeastern Mediterranean Sea, Turkey. Since it has been recorded only once in the last sixty years, this species could be considered as exceptionally rare in the easternmost area of the Mediterranean Sea, Turkey.
\end{abstract}

Erguden, D., Bayhan, Y. K., Erguden, S. A., Altun, A. (2018): The occurrence of royal flagfin Aulopus filamentosus (Bloch, 1792) in Mersin bay (North Eastern Mediterranean) Turkey. Croatian Journal of Fisheries, 76, 51-54. DOI: $10.2478 /$ cjf-2018-0006.

\section{INTRODUCTION}

The family Aulopidae is represented in Mediterranean waters with a single genera and a single species (Froese and Pauly, 2016): Aulopus filamentosus (Bloch, 1792). A. flamentosus mostly inhabits muddy and sandy bottoms at maximum depths of 100-200 m (Sulak, 1990) and is widely distributed in the northern Atlantic and western central Atlantic from Senegal to the Caribbean and Venezula and the Mediterranean, except the eastern part (Sulak, 1984; Carvalho-Filho et al., 2010).

Occurrence of A. filamentosus in the Mediterranean was reported from Italian waters by Tortonese $(1947 ; 1970)$.
Further reports of the species have been given from off the Tunisian, Egyptian and Libyan waters (Ben Souissi et al., 2010; El Sayed, 1994; Al-Hassan and El- Silini, 1999), as well as the presence in Adriatic waters (Dulčić, 2006). In the eastern Mediterranean this species has been reported from Greek Aegean waters (Economidis, 1973), the Turkish Mediterranean coast (Akşıray, 1954 and Bilecenoglu et al., 2002a), Syrian waters (Saad, 2005) and the coast of Israel (Golani, 2005; Golani et al., 2006), easternmost limits of the extension range of the species.

First report of $A$. filamentosus from Turkish waters of the Mediterranean Sea was made in 1954 (Akşıray, 1954) and the presence of the species in Turkey was confirmed 
with a single record from the Babakale coast, Çanakkale in the northern Aegean Sea (Işmen et al., 2006). Deepsea fishing off the coast of Turkey in the northeastern Mediterranean has only begun in recent decades and fishing activity goes further off the coast continually which results in the extension of the range of fishing area up to the continental slope and causes the capture of fish from new regions. As a result, a number of rare and new demersal species have, nowadays, been captured from the Mediterranean Sea with bottom trawls (Bayhan et al., 2015).

Although $A$. filamentosus is recorded in the Mediterranean Sea coast of Turkey, the species is rare and no specimens up to now have been reported from the northeastern Mediterranean waters of Turkey. This study reports the first occurrence of $A$. filamentosus from Mersin Bay and confirms the presence of the species in the northeastern Mediterranean Sea coast of Turkey.

\section{MATERIALS AND METHODS}

On 23 June 2015, three specimens ( 1 male and 2 female) of the royal flagfin $A$. filamentosus (Bloch, 1792) were captured at a depth of $184 \mathrm{~m}$ with a commercial bottom trawl from north- east of Erdemli (36 $26^{\circ} 852^{\prime \prime} \mathrm{N}-34^{\circ}$ 39' 609” E) in Mersin Bay (northeastern Mediterranean, Turkey) (Fig 1) Morphometric measurements of the three specimens were made to the nearest $0.1 \mathrm{~mm}$ using digital caliper. All measurements and counts, and the morphological description and colour agree with the descriptions of Sulak (1984), Ben Souissi et al. (2010) and Carvalho-Filho et al. (2010). The specimens are deposited in the Museum of the Faculty of Marine Sciences and Technology, Iskenderun Technical University, with catalogue numbers (MSM-PIS/2015-4, MSM-PIS/2015-5 and MSM- PIS/2015-6) (Fig. 2)

\section{RESULTS}

The Mediterranean specimen of $A$. filamentosus is described as follows: body moderately elongated and slender; head conical and large; snout relatively long and depressed; eyes large; upper jaw expanded posteriorly with two supramaxillaries, reaching to or beyond the eye center. First 2-4 dorsal fin rays in males elongated; a small adipose fin above midpoint of anal fin; anal fin, shorter and lower than the dorsal fin; pelvic fin large, longer than pectoral; caudal fin forked. Scales ctenoid, adherent, small axillary scales present at bases of pectoral and pelvic fins. The distinguishing meristic and morphometric characteristics of the three specimens are given in Table 1. Color greenish-brown to olive, with darker saddles and lateral blotches; head darker, purplish to pink; upper body and head suffused with yellow; dorsal fin tip black;

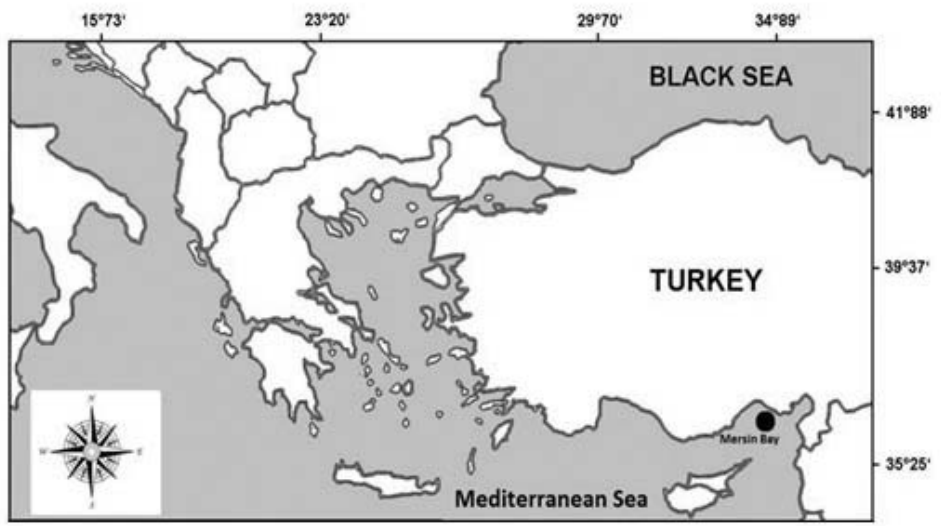

Fig 1. Map of Turkey, showing the collection site $(\bullet)$ of Aulopus filamentosus

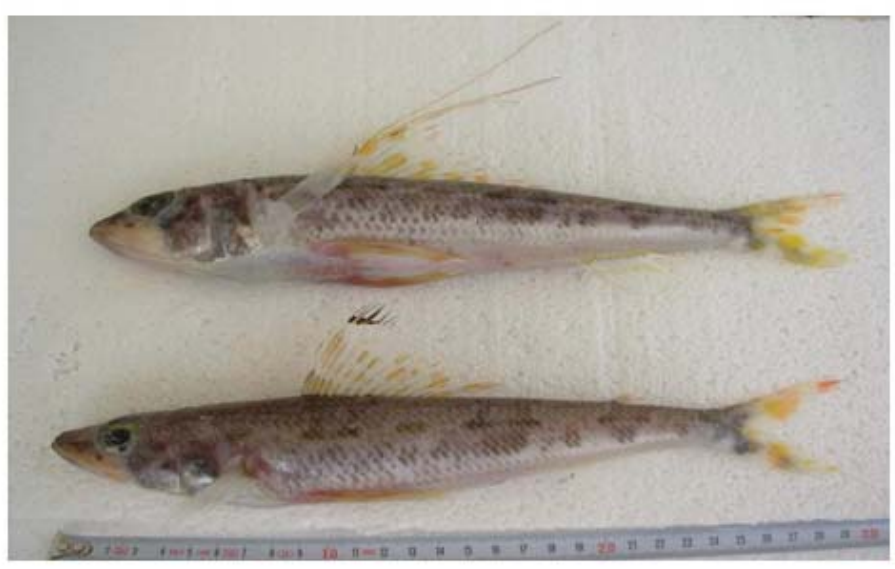

Fig 2. Male (above) and female (below) specimens of Aulopus filamentosus, $290 \mathrm{~mm}$ total length, (MSM-PIS/2015-4) and $285 \mathrm{~mm}$ total length, (MSM-PIS/2015-5) from Mersin Bay, northeastern Mediterranean Sea, Turkey

the males are more brightly colored, with red, orange and yellow markings, and bars on fins, but females might also present smaller reddish to orange marks on fins; color in the scales are iridescent with transverse bands, and the belly silvery to whitish or light pink; adipose fin tip yellowishgreen to orange.

\section{DISCUSSION}

A. filamentosus is a demersal species which lives in Atlantic and Mediterranean waters (Froese and Pauly, 2016) and reaches $440 \mathrm{~mm}$ standard length (SL) (Sulak, 1990). It commonly feeds on small fishes (Sulak, 1984). According to the previous records of $A$. filamentosus in the Mediterranean, this species is considered as a rare fish and its eastward distribution in the Mediterranean Sea appears 
Table 1. Morphometric measurements (in $\mathrm{mm}$ and as $\% \mathrm{TL}, \% \mathrm{HL}$ ), meristic counts and masses recorded in three Aulopus filamentosus caught in northeastern Mediterranean waters

\begin{tabular}{|c|c|c|c|c|c|c|}
\hline Metric (mm) & Male & $\%$ & Female & $\%$ & Female & $\%$ \\
\hline Specimen & 1 & & 1 & & 1 & \\
\hline Total length & 290 & - & 285 & - & 230 & - \\
\hline Fork length & 265 & $91.37 \mathrm{TL}$ & 260 & $91.22 \mathrm{TL}$ & 215 & 93.47TL \\
\hline Standard length & 253 & 87.24 TL & 247 & 86.66 TL & 201 & 87.39 TL \\
\hline Head length & 56 & $19.31 \mathrm{TL}$ & 55 & 19.29 TL & 46 & $20.00 \mathrm{TL}$ \\
\hline Eye width & 17 & $30.35 \mathrm{HL}$ & 17 & $30.90 \mathrm{HL}$ & 15 & $32.60 \mathrm{HL}$ \\
\hline Eye diameter & 18 & $32.14 \mathrm{HL}$ & 18 & $32.72 \mathrm{HL}$ & 11 & $23.91 \mathrm{HL}$ \\
\hline Inter orbital distance & 15 & $26.78 \mathrm{HL}$ & 13 & $23.63 \mathrm{HL}$ & 13 & $28.26 \mathrm{HL}$ \\
\hline Pre-orbital length & 23 & $41.07 \mathrm{HL}$ & 23 & $41.81 \mathrm{HL}$ & 18 & $39.13 \mathrm{HL}$ \\
\hline Post-orbital length & 42 & $75.00 \mathrm{HL}$ & 40 & $72.72 \mathrm{HL}$ & 33 & $71.73 \mathrm{HL}$ \\
\hline Mouth & 37 & $66.07 \mathrm{HL}$ & 34 & $61.81 \mathrm{HL}$ & 29 & $63.04 \mathrm{HL}$ \\
\hline Snout length & 08 & $14.28 \mathrm{HL}$ & 11 & $20.00 \mathrm{HL}$ & 07 & $15.21 \mathrm{HL}$ \\
\hline Body depth & 38 & 13.10 TL & 38 & $13.33 \mathrm{TL}$ & 30 & 13.04 TL \\
\hline Caudal peduncle & 15 & $5.17 \mathrm{TL}$ & 16 & $5.61 \mathrm{TL}$ & 13 & $5.65 \mathrm{TL}$ \\
\hline Pre-dorsal length & 93 & $32.06 \mathrm{TL}$ & 92 & $32.28 \mathrm{TL}$ & 80 & $34.78 \mathrm{TL}$ \\
\hline Pre-pectoral length & 74 & $25.51 \mathrm{TL}$ & 73 & $25.61 \mathrm{TL}$ & 62 & $26.95 \mathrm{TL}$ \\
\hline Pre-anal length & 178 & $61.38 \mathrm{TL}$ & 177 & $62.10 \mathrm{TL}$ & 147 & $63.91 \mathrm{TL}$ \\
\hline Pre-ventral length & 91 & $31.38 \mathrm{TL}$ & 92 & $32.28 \mathrm{TL}$ & 75 & $32.60 \mathrm{TL}$ \\
\hline Ventral-anal distance & 91 & $31.38 \mathrm{TL}$ & 98 & $34.38 \mathrm{TL}$ & 79 & $34.34 \mathrm{TL}$ \\
\hline Pectoral-ventral distance & 12 & 4.13 TL & 15 & $5.26 \mathrm{TL}$ & 16 & $6.95 \mathrm{TL}$ \\
\hline Pectoral-dorsal distance & 27 & $9.31 \mathrm{TL}$ & 21 & $7.36 \mathrm{TL}$ & 21 & $9.13 \mathrm{TL}$ \\
\hline Pectoral-anal distance & 92 & $31.72 \mathrm{TL}$ & 98 & $34.38 \mathrm{TL}$ & 91 & $39.56 \mathrm{TL}$ \\
\hline Total weight (g) & 210.333 & & 189.623 & & 99.541 & \\
\hline \multicolumn{7}{|l|}{ Meristic } \\
\hline Dorsal fin ray & 15 & & 15 & & 14 & \\
\hline Pectoral fin ray & 13 & & 13 & & 13 & \\
\hline Anal fin ray & 11 & & 11 & & 11 & \\
\hline Ventral fin ray & 9 & & 9 & & 9 & \\
\hline Caudal fin ray & 21 & & 21 & & 20 & \\
\hline Gill rakers & 14 & & 14 & & 13 & \\
\hline Lateral line scales & 53 & & 53 & & 52 & \\
\hline
\end{tabular}

to be limited (Akşıray, 1954; İşmen et al., 2006).

Deep-sea research in marine waters of Turkey has been limited until the last two decades, but recent exploratory fishing activities have resulted in the report of a number of new records and new species for the Mediterranean and Aegean Sea (Bilecenoglu et al., 2002b; Deval, 2013; Bilecenoglu et al., 2014; Ergüden and Bayhan, 2015; Bayhan et al., 2015) coast of Turkey. The first samples of $A$. filamentosus were caught in 1950 s by Akşıray (1954) in the Mediterranean coast of Turkey. Present report is the first confirmation of the presence of the species in the northeastern Mediterranean (Mersin, Turkey) with three ( 1 male and 2 females) individuals caught approximately after 60 years of its first appearance in Turkish marine waters. 


\section{ACKNOWLEDGEMENTS}

We would like to thank the owner of the Çınar Bey Boat, Captain Murat, ÇINAR and the boat staff for their assistance in this study.

\section{SAŽETAK}

\section{POJAVNOST Aulopus filamentosus (Bloch, 1792) U ZALJEVU MERSIN (SJEVEROISTOČNI MEDITERAN) TURSKA}

Ulovljena su tri primjerka ( 1 mužjak i 2 ženke) barjaktarke, Aulopus filamentosus (Bloch, 1792), na dubini od $184 \mathrm{~m}$ u gradu Erdemli, u zaljevu Mersin (sjeveroistočni Mediteran, Turska) u lipnju 2015. godine. U ovom je radu prikazano prvo pojavljivanje te je potvrda barjaktarke, A. filamentosus, iz sjeveroistočnog Sredozemnog mora u Turskoj. S obzirom da je zabilježena samo jednom u posljednjih šezdeset godina, ova vrsta smatra se iznimno rijetkom u najistočnijem dijelu Sredozemnog mora (Turska).

Ključne riječi: Aulopus filamentosus, zaljev Mersin, Sredozemno more, Turska

\section{REFERENCES}

Akşıray, F. (1954): Türkiye Deniz Baliklari Tayin Anahtari. İstanbul: İstanbul Üniversitesi Fen Fakültesi Hidrobiyoloji Araştırma Enstitüsü Yayınları.

Al-Hassan, L. A. J., El-Silini, O. A. (1999): Check-list of bony fishes collected from the Mediterranean coast of Bengazi, Libya. Revista de Biologia Marina y Oceanografía, 34, 2, 291-301.

Bayhan, Y. K., Erguden, D., Altun, A. (2015): Records of Stomias boa boa (Risso, 1810) and Nemichthys scolopaceus Richardson, 1848 from Mersin Bay, Turkey. Journal of Applied Ichthyology, 31, 5, 922-923.

Ben Souissi, J., Ben Abdallah, L. G., Ben Amor, M. M., Ben Salem, M., Capapé, C. (2010): Confirmed occurrence of the royal flagfish, Aulopus filamentosus (Osteichthyes: Aulopidae) in Tunisian waters (Central Mediterranean). Pan-American Journal of Aquatic Sciences, 5, 1, 157-161.

Bilecenoglu, M., Taskavak, E., Mater, S., Kaya, M. (2002a): Checklist of the marine fishes of Turkey. Zootaxa, 113, 1-194.

Bilecenoğlu, M., Kunt, K. B., Taşkavak, E. (2002b): First record of Mora moro (Risso, 1810) (Pisces, Moridae) from the eastern Mediterranean Sea. Israel Journal of Zoology, 48, 243-244.

Bilecenoğlu, M., Kaya, M., Cihangir, B., Çiçek, E. (2014): An updated checklist of the marine fishes of Turkey.
Turkish Journal of Zoology, 38, 901-929.

Carvalho-Filho, A., Marcovaldi, G., Sampaio, C. L. S., Isabel, M., Paiva, G., Duarte, L. A. G. (2010): First report of Aulopus (Teleostei: Aulopidae) from Southwestern Atlantic, with a review of records and a key to Western Atlantic Aulopoidei species. Zootaxa, 2628, 27-42.

Deval, C. (2013): New records and uncommon occurrences of deepwater fishes in theTurkish Mediterranean Sea (Osteichthyes). Zoology in the Middle East, 59, 308-313.

Dulčić, J. (2006): On the record of the royal flagfin, Aulopus filamentosus (Pisces: Aulopidae), from the Adriatic Sea. Annales, Series Historia Naturalis, 16, 2, 189-192. Economidis, P. S. (1973): Catalogue of the fishes of Greece. Hellenic Oceanology and Limnology, 11, 421-600.

El Sayed, R. S. (1994): Check-List of Egyptian Mediterranean Fishes. Alexandria, Egypt: Institute of Oceanography and Fisheries.

Ergüden, D., Bayhan, K. Y. (2015): Three fish species known to be rare for Turkey, captured from the Northeastern Mediterranean coast of Turkey, Mersin Bay, Sudis hyalina Rafinesque, Chlopsis bicolor Rafinesque, Squatina aculeata Cuvier. International Journal of Scientific and Technological Research, 1, 4, 1-8.

Froese, R., Pauly, D. (Eds) (2016): FishBase (www Database). [Cited 06 June 2016].World Wide Web electronic publication. Available from: http://www.fishbase.org.

Golani, D. (2005): Checklist of the Mediterranean Fishes of Israel. Zootaxa, 947, 1-90.

Golani, D., Öztürk, B., Basusta, N. (2006): Fishes of the Eastern Mediterranean. Turkish Marine Research Foundation (TUDAV), İstanbul.

İşmen, A., Yığın, Ç., Çakır, F. (2006): A new fish species for the northern Aegean Sea fauna; Aulopus filamentosus (Bloch, 1792). E.U. Journal of Fisheries \& Aquatic Sciences, 23, Suppl. 1/1, 95-97.

Saad, A. (2005): Check-list of bony fish collected from the coast of Syria. Turkish Journal of Fisheries and Aquatic Sciences, 5, 99-106.

Sulak, K. J. (1984): Aulopidae. pp. 403-404. In: Whitehead, P. J. P., Bauchot, M. L., Hureau, J. C., Nielsen, J., Tortonese, E. (eds), Fishes of the North-eastern Atlantic and the Mediterranean. Vol. I, Paris: UNESCO.

Sulak, K. J. (1990): Aulopidae. pp. 349-350. In: Quero, J. C., Hureau, J. C., Karrer, C., Post, A., Saldanha, L. (eds), Check-list of the fishes of the eastern tropical Atlantic (CLOFETA). JNICT, Lisbon; SEI, Paris; and UNESCO, Paris. Tortonese, E. (1947): Ricerche zoologiche nell'isola di Rodi (Mar Egeo) - Pesci. Bolletino di Pesca, Piscicoltura e Idrobiologia, 23, 2, 143-192.

Tortonese, E. (1970): Osteichthyes (Pesci ossei). Parte prima. In: Fauna d'Italia. Calderini, Bologna, 564. 